\title{
10
}

\section{Does the Development of the Agricultural Sector Affect the Manufacturing Sector?}

\section{Namalguebzanga Christian Kafando}

\subsection{Introduction}

In the mid-twentieth century, most African countries proclaimed their independence and resolved to progress economically from low valueadded primary activities to high value-added manufacturing activities. This process which is referred to as "industrialization" was considered as the main means of evolving from developing to developed or industrialized countries. In 1986, consensus on this process also emerged within the Organization of African Unity (OAU) in Africa's Priority Programme for Economic Recovery 1986-1990. Soon after independence, African countries tried to build an industrial sector-driven economy. Unfortunately, this strategy failed especially due to very strong State interference in the economic sector and a difficult global context (Hughes 1984; Hawkins 1986).

N. C. Kafando $(\bowtie)$

United Nations Industrial Development Organization, Abuja, Nigeria

(C) The Author(s) 2018 
This explains why Africa is the only continent that has not benefited from an expansion of the industrial development model but also the most marginalized continent with regard to manufacturing output and world trade (UNCTAD 2011). Very recently, however, the United Nations Economic Commission for Africa and the African Union seemed to have underscored the need to revamp industrial policy in Africa. "Given that most African countries now have a comparative advantage in commodities, industrialization based on the exploitation of natural resources is a means for developing regional value chains on the continent, and African countries should take advantage of this opportunity" (ECA and AUC 2013; UNCTAD 2013).

This study is carried out within this framework for reasons presented earlier and focuses on the contribution of the agricultural sector to industrial development. This sector has already been the subject of a consensus at the continental level through the 2003 Maputo (Mozambique) Declaration. The objective of this Agreement, which was materialized by the adoption of the Comprehensive Africa Agriculture Development Programme (CAADP), is to improve the contribution of the agricultural sector to the economic growth of African countries. This objective is especially commendable as this sector is vital to industrial development.

The main objective of this study is to understand the contribution of agricultural activities to the development of the manufacturing sector in African countries but also to determine if and how all African countries can take advantage of the industrial development process. The study is divided into four parts. Part I presents a review of the relevant literature and identifies the variables used for the study. Part II presents the analytical framework and a statistical description of the links between the agricultural and manufacturing sectors in Africa, while making a distinction between the different regions. This distinction is necessary because the industrial sector comprises several sectors, namely manufacturing, mining and oil (Lewis 1954). The study focuses on the manufacturing industry because it is the only sector that can be affected by the agricultural sector. Part III analyses the contribution of agricultural activities to the development of the manufacturing sector in African economies using econometrics. In other words, the study examines the relationship between the levels of agriculture value added and those of the 
manufacturing sector in African countries, taking into account growth factors (physical capital, human capital and economic openness) and the quality of governance. The regressions made is based on fixed effects models, double fixed effects models and the generalized least-squares estimator. Part IV presents and interprets the implications in order to draw conclusions in terms of economic policies.

\subsection{Literature Review}

Concerning the development outlook of African countries, we have seen that some studies suggest that these countries should only specialize in the production of natural resources in which they have a comparative advantage (Wood and Mayer 2001; Park and Lee 2006; Mayer and Fajarnes 2008). On the other hand, other authors have upheld that industrialization is necessary because it constitutes the key element in efforts to close the economic gap (Cornwall 1977; Tregenna 2007; Szirmai and Verspagen 2011). Agriculture alone cannot steer countries on the path of strong growth because, according to classical economic theories, the value added of output per capita generated by the agricultural sector is less than the one generated by the industrial sectors although it is vital for industrial development (Lewis 1954).

The level of development of the agricultural sector can be considered as a mean of developing the industrial sector. This feature also has many advantages. "One of the most striking features of developing countries is a weak linkage between agriculture and industry. That is why agriculture cannot experiment new inputs such as fertilizers and machinery" (Abdelmalki and Mundler 1995). After examining the importance of agriculture in the development of manufacturing activities in the economy on a global sample and taking into account some regions using dummy variables, Shifa (2011) observed that this impact is positive and proportional to the share of agriculture in the economy. Mellor (1966) argues that an increase in the size of the agricultural sector promotes natural transformation. This enables the economy to evolve from a situation dominated by a slow-growing agricultural sector to another dominated by a fast-growing non-agricultural sector. 
Many authors have pointed out the importance of the agricultural sector for the take-off of industrial development (Bairoch 1971; Kuznets 1966; Fei and Ranis 1969). Mellor (1966) explains that change in economic structure is due to the size of the agricultural sector rather than its growth rate which is slow. According to him, the improvement of human capital and dissemination of knowledge promotes agricultural development through the accumulation and distribution of capital among sectors, the specialization of economies and economic openness. Balassa (1979) argues that differences in physical and human capital lead to differences in the performance of the manufacturing sectors of economies. According to him, population growth, which is often regarded as a drag on development, veils a combination of human creativity and the accumulation of scientific knowledge which help to improve technology. The use of technology in the production system leads to an increase in agricultural sector productivity. This productivity is subsequently enhanced by the advantages related to specialization in a given sector of production. There are two advantages of specialization: it reduces transaction costs and increases the volume of trade.

In reality, most of the explanations given for the impact of the size of the agricultural sector on the industrial sector are based on the concept of surplus. Some authors (Lewis 1954; Fei and Ranis 1969; Abdelmalki and Mundler 1995) have also tried to explain this change using the concept of agricultural surplus which is transferred to the manufacturing sector. Agricultural surplus may be in the form of workforce, additional production or additional income.

The concept of agricultural surplus (Lewis 1954) may vary depending on whether we are addressing supply and demand, the labour market, the self-financing of the economy or global trade issues (Abdelmalki and Mundler 1995). Thus, four definitions of surplus can be proposed.

Concerning the supply of and demand for agricultural products, an increase in production helps to meet the needs of the farm population and the rest of the population. Part of the agricultural surplus generated can also be used or processed by the industrial sector. An increase in the supply of agricultural products leads to a drop in the prices of those products which also bring about a reduction in wage costs in all sectors of the economy. 
Regarding the labour supply and demand market, an increase in agricultural sector productivity will release surplus labour which will be available to other economic sectors.

Breakthroughs in agriculture help to mobilize "forced" or "voluntary" savings that could lead to economic self-financing (Abdelmalki and Mundler 1995). Savings are considered as forced when they are generated in the form of taxes or levies on proceeds of the sale of agricultural products. The State plays a key role by forcibly mobilizing financial resources which are reinjected into the economy. Savings are voluntary when they are made by the farmers themselves in the sense that surplus profit is reinvested through the acquisition of means to improve production or productivity or simply as a means for future consumption. According to Abdelmalki and Mundler (1995), in both cases, farmers' actions help to stimulate demand.

Through exports of agricultural products, local economic actors earn foreign exchange which is used to finance the industrial sector (Mellor 1966; Abdelmalki and Mundler 1995). In this case, export earnings would depend on terms of trade corresponding to purchasing power (Abdelmalki and Mundler 1995). The terms of trade are favourable when export prices increase faster than import prices and unfavourable otherwise.

Besides these elements, the way a country is governed can determine its capacity to mobilize resources. Auty (2000) argues that governance that allows for the implementation of reforms by encouraging the development of manufacturing sector activities enables the economy to experience sustainable and equitable growth. In contrast, a government controlled by a group of people does not allow the establishment of such a virtuous circle. According to this model, the quality and type of governance determine the capacity of an economy to industrialize. Collier (2002) believes that poor governance is linked to dependence on primary commodities. Though this dependence can impede the development of manufacturing industries, bad institutions can lead to poor performance.

This literature review has helped to identify the size of the agricultural sector as a vehicle of industrial development and the factors (investment, human capital, governance quality and economic openness) that contribute to industrial development. 


\subsection{Analytical Framework}

To measure the size that incorporates the effects of productivity and agricultural sector surplus, we considered the per capita value added created by this sector (agrvapc, WB). To take into account the investment made in the economy as a whole, we considered gross fixed capital formation per capita (gfcfpc, UNCTAD). Since human capital can boost manufacturing and agricultural sector productivity, we use an index to measure the development potential of human capital that is the "Human Asset Index (HAI)" (UN DESA, FERDI, 2011). Since proper resource allocation depends on governance and can promote or hinder manufacturing sector development, we conceptualized it by measuring good governance, denoted as "qogov" (ICRG). Economic openness is considered through the Penn World Table 7 "openc" variable. Lastly, as dependent variable, instead of using the industrial sector as a whole, we opted for the manufacturing sector which lies at the very heart of the ripple effects linked to the industrial sector. This level of manufacturing is just like that of the agricultural sector which is measured by its value added per capita (manufacturing value added per capitaMVAPC, UNCTAD). The period covered by the data runs from 1980 to 2009, which means 30 years.

Thus, in light of the various contributions of the literature presented earlier, we retain the size of the agricultural and manufacturing sectors rather than their growth rate.

We present two types of models. Unlike the first model, the second includes temporal dummies $\left(f_{t}\right)$ to consider temporary shocks.

The models can be presented as follows with $X$ representing the vector of control variables:

$$
\operatorname{mvapc}_{i, t}=\operatorname{agrvapc}_{i, t-1}^{\beta} \times X_{i, t}^{\delta}
$$

When expressed in logarithmic form, Eq. 10.1 is as follows:

$$
\ln \operatorname{mvapc}_{i, t}=\alpha+\beta \operatorname{agrcapc}_{i, t-1}+\delta X_{i, t-1}+f_{t}+\varepsilon_{i ; t}
$$


where MVAPC represents the value added per capita, $a$ the constant of the model, $\beta, \delta$ the coefficients of the variables measuring the effects of agricultural value added and control variables, namely the level of investment per capita, a variable estimating the value of human capital, economic openness, governance quality and the fixed effects of the period on the dependent variable. The notation $t-1$ means that we have considered lagged variables as current variables could be endogenous to the dependent variable. Agriculture does not have an immediate effect on manufacturing activities. The effects of an increase in the size or scale of agricultural production take a long time to manifest themselves (Studennund 2000). "Any change in an agricultural market, such as an increase in the price that the farmer can earn for providing cotton, has a lagged effect on the supply of that product" (Studennund 2000). Then, where there is change in demand in the agricultural products processing sector during the period $t$, agricultural sector producers will adapt their supply during the period $t+1$. Thus, the use of the lagged value of agricultural value added per capita helps to take these aspects into account. Thus, it is easy to imagine, for example, that agricultural production during $t-1$ can have an impact on the production of manufactured goods related to the processing of agricultural products. The same applies to levels of investment, education and exports during $t-1$. These reasons help to justify the use of lagged variables as a means to address endogenous phenomena like Barro (1998) did in his studies on growth. Thus, all independent variables will be modified by their lagged value in a given year, except our measurement of governance quality.

We estimate the model below using a sample of 37 African countries, making sure to distinguish the regions (excluding countries for which we do not have sufficient observations ${ }^{1}$ on governance quality) (Table 10.1 shows descriptive statistics). For all the samples studied, the data are divided into three-year periods, which represent a total of ten periods. The notation " $P$ " means that the variables are lagged.

$$
\ln \text { mvapc }_{i, t}=\alpha+\beta l \cdot \ln \operatorname{agrcapc}_{i, t-1}+\delta X_{i, t-1}+f_{t}+\varepsilon_{i ; t}
$$


Table 10.1 Country classification by region

\begin{tabular}{|c|c|c|c|c|c|}
\hline \multirow[b]{2}{*}{ Regions } & \multirow{2}{*}{$\begin{array}{l}\text { Indicators } \\
\text { Countries }\end{array}$} & \multicolumn{2}{|c|}{$\begin{array}{l}\text { Manufacturing value } \\
\text { added per capita in USD }\end{array}$} & \multicolumn{2}{|c|}{$\begin{array}{l}\text { Agricultural value added } \\
\text { per capita in USD }\end{array}$} \\
\hline & & $\begin{array}{l}\text { Median } \\
\text { values }\end{array}$ & $\begin{array}{l}\text { Regional } \\
\text { median }\end{array}$ & $\begin{array}{l}\text { Median } \\
\text { values }\end{array}$ & $\begin{array}{l}\text { Regional } \\
\text { median }\end{array}$ \\
\hline Southern & South Africa & 808 & 233 & 122 & 121 \\
\hline \multirow{6}{*}{ Africa } & Malawi & 20 & & 65 & \\
\hline & Namibia & 351 & & 316 & \\
\hline & Botswana & 175 & & 128 & \\
\hline & Zambia & 61 & & 134 & \\
\hline & Zimbabwe & 52 & & 71 & \\
\hline & Mozambique & 21 & & 66 & \\
\hline North & Algeria & 169 & 212 & 206 & 217 \\
\hline \multirow[t]{4}{*}{ Africa } & Egypt & 154 & & 163 & \\
\hline & Morocco & 256 & & 262 & \\
\hline & Libya & 374 & & 184 & \\
\hline & Tunisia & 400 & & 278 & \\
\hline Central & Angola & 90 & 28 & 206 & $206^{a}$ \\
\hline \multirow[t]{4}{*}{ Africa } & Cameroon & 166 & & 178 & \\
\hline & $\begin{array}{l}\text { Central African } \\
\text { Republic }\end{array}$ & 28 & & 177 & \\
\hline & Gabon & 19 & & 251 & \\
\hline & $\begin{array}{l}\text { Equatorial } \\
\text { Guinea }\end{array}$ & 8 & & 252 & \\
\hline \multirow[t]{4}{*}{ East Africa } & Kenya & 58 & 29.5 & 131 & 148 \\
\hline & Somalia & 6 & & 165 & \\
\hline & Sudan & 37 & & 206 & \\
\hline & Tanzania & 22 & & 96 & \\
\hline West & Côte d'Ivoire & 155 & 43 & 283 & 164 \\
\hline \multirow[t]{7}{*}{ Africa } & Benin & 39 & & 161 & \\
\hline & Ghana & 78 & & 205 & \\
\hline & Guinea-Bissau & 46 & & 210 & \\
\hline & Liberia & 14 & & 167 & \\
\hline & Senegal & 98 & & 117 & \\
\hline & Sierra Leone & 20 & & 159 & \\
\hline & Togo & 32 & & 152 & \\
\hline
\end{tabular}

Sources: Calculations made by the author based on data derived from the United Nations Conference on Trade and Development (UNCTAD) and Penn World Table (PWT) 7.0; Alan Heston, Robert Summers and Bettina Aten, Penn World Vision 7.0, Center for International Comparisons of Production, Income and Prices at the University of Pennsylvania, May 2011 a206 is the median value of the Agricultural value added per capita in USD in 
Table 10.2 Generalized Hausman test

\begin{tabular}{lrrr}
\hline & \multicolumn{1}{l}{ 4 } & \multicolumn{1}{l}{5} \\
\hline Africa & $320.42 * * *(0.0000)$ & $380.90 * * *(0.0000)$ & $411.89 * * *(0.0000)$ \\
Southern Africa & $77.88 * * *(0.0000)$ & $63.17 * * *(0.0000)$ & $59.64 * * *(0.0000)$ \\
North Africa & $56.25 * * *(0.0000)$ & $82.22 * * *(0.0000)$ & $114.76 * * *(0.0000)$ \\
East Africa & $53.55 * * *(0.0000)$ & $353.25 * * *(0.0000)$ & $447.58 * * *(0.0000)$ \\
Central Africa & $80.19 * * *(0.0000)$ & $223.50 * * *(0.0000)$ & $232.53 * * *(0.0000)$ \\
West Africa & $149.83 * * *(0.0000)$ & $158.00 * * *(0.0000)$ & $162.93 * * *(0.0000)$ \\
\hline
\end{tabular}

Robust $p$ value in parentheses

$* * * p<0.01, * * p<0.05, * p<0.1$

We identified five subsamples in all, with each subsample representing a region. Thus, we make a distinction between North Africa, Southern Africa, West Africa, Central Africa and East Africa.

As the right model to use on our different panels could not be determined by the usual Hausman test, we used a generalized Hausman test which is in fact an increased regression that is asymptotically equivalent to the Hausman test (Wiggins 2003). The results of the test (Table 10.2) suggest that the fixed effects model is preferable to the random effects model for all samples. Later on, we used double effects fixed models, which are models that take into account countries characteristics and the effects that are specific to each period. Since the use of lagged values for some variables does not help to eliminate all the probability of endogenous factors in so far as hysteresis effects may still exist, we used the dynamic panel estimator of the generalized moments method (GMM) in first two-step differences based on the works of Arellano and Bond (1991), Arellano and Bover (1995) and Blundell and Bond (1998) (Roodman 2006). This is an estimator that is especially adapted to samples with many individuals (37 countries in our sample) and few periods (ten periods of three years each in our study). This estimator helps to eliminate order 1 autocorrelation, making it possible to validate the exogenous factors of the instruments used. This method was therefore used to estimate the following dynamic model (Eq. 10.4):

$$
\begin{aligned}
\ln _{\text {mvapc }_{i, t}=} & \alpha+\alpha \quad l . \ln \operatorname{agrcapc}_{i, t-1}+\beta l . \ln \operatorname{agrcapc}_{i, t-1} \\
& +\delta X_{i, t-1}+f_{t}+\varepsilon_{i ; t}
\end{aligned}
$$


We applied the Windmeijer correction method (2005) to minimize residuals (Roodman 2006). To verify if error terms do not correlate, we also carried out a Sargan/Hansen test. Unfortunately, given the size of the sample at the regional level, it was not possible for us to carry out this robustness test for the different regions. However, we were able to do so for the bulk sample (i.e., the 37 countries).

Before interpreting the results of the models described earlier, we present the statistical analysis of the data used in this empirical study.

\subsection{Description of Variables}

To better understand the relationships between our two variables of interest in Africa, it is necessary to compare manufacturing value added per capita with agriculture value added per capita. The data concerning value added by sector and level of investment are expressed in 2005 dollar per capita.

The curves in Graph 10.1 suggest that manufacturing value added is lower than agricultural value added. This shows that the industrial sector is not the key economic sector in Africa.

It should, however, be noted that during the 1998-2009 period, the per capita value added of these two sectors seems to be correlated. This can also be interpreted as a change in trend in recent years. One of the reasons for such change may be the use of agricultural surplus in the processing sector.

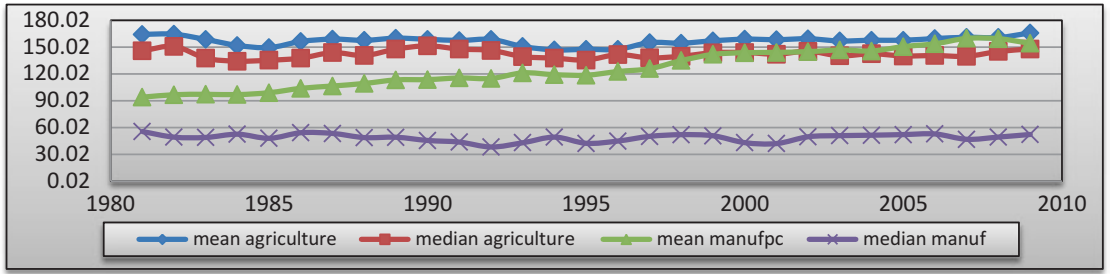

Graph 10.1 Manufacturing and agricultural value added per capita. Sources: Calculations made by the author based on data derived from the United Nations Conference on Trade and Development (UNCTAD) and Penn World Table (PWT) 7.0; Alan Heston, Robert Summers and Bettina Aten, Penn World Vision 7.0, Center for International Comparisons of Production, Income and Prices at the University of Pennsylvania, May 2011 
However, the explanation is much more complex than it seems. Concerning the manufacturing sector, this same graph suggests that its value added per capita increased on average during the entire period. This difference between the median and the sector average very clearly suggests that the countries in the sample did not experience similar trends.

These initial differences do not bar us from asserting that there is a positive correlation between the two sectors (Graph 10.2). We opted to further analyse the data to better understand the differences that may exist at the regional level (Graph 10.3).

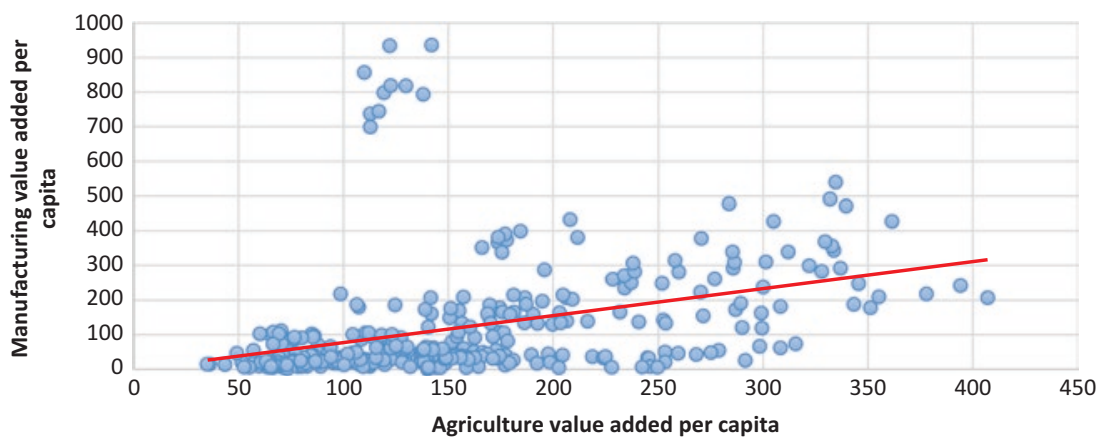

Graph 10.2 Linear trend in agricultural and manufacturing sector value added. Sources: Calculations made by the author based on data derived from the United Nations Conference on Trade and Development (UNCTAD) and Penn World Table (PWT) 7.0; Alan Heston, Robert Summers and Bettina Aten, Penn World Vision 7.0, Center for International Comparisons of Production, Income and Prices at the University of Pennsylvania, May 2011

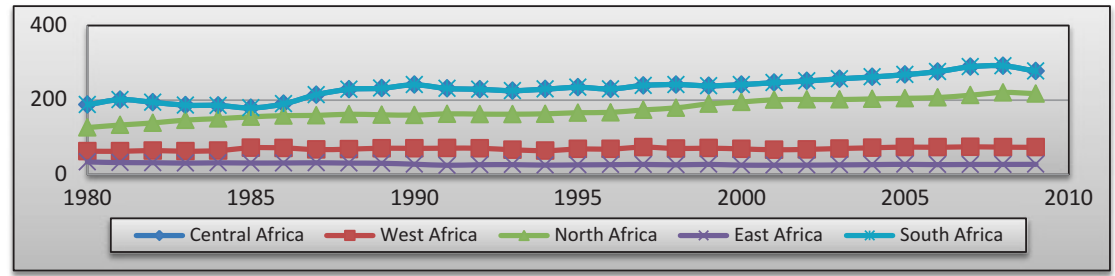

Graph 10.3 Manufacturing sector value added by region. Sources: Calculations made by the author based on data derived from the United Nations Conference on Trade and Development (UNCTAD) and Penn World Table (PWT) 7.0; Alan Heston, Robert Summers and Bettina Aten, Penn World Vision 7.0, Center for International Comparisons of Production, Income and Prices at the University of Pennsylvania, May 2011 
When the curves (Graphs 10.4, 10.5, 10.6, 10.7, and 10.8 presented in Annexes) representing value added per capita in the regions that make up our sample are spontaneously analysed, two regions stand out from the rest. These regions are clearly responsible for the increase in the manufacturing average during the period considered in the analysis. These regions are Southern Africa (Graph 10.4) and North Africa (Graph 10.5). Since population size is considered, if we limit ourselves to the conclusions of development theories, it may be argued that the productivity rate in the manufacturing sector in these two regions is higher than the population growth rate. The other three regions, namely West, Central and East Africa are at the bottom of the scale. Each of them has barely one-third of the per capita value added generated by the manufacturing industry in North Africa. Rather than limiting ourselves to these initial findings concerning the different regions, we went on to compute and compare the growth rates of the manufacturing sector with those of the agricultural sector and the population (Table 10.3).

The analysis in Table 10.3 shows that in Africa the average growth rate of manufacturing sectors is lower than that of the agricultural sector and the

Table 10.3 Comparison between the manufacturing and agricultural sectors and population size in Africa

\begin{tabular}{lllllll}
\hline Indicators & Africa & North & South & West & Centre & East \\
\hline $\begin{array}{c}\text { Average level of agriculture } \\
\text { Average level of }\end{array}$ & 2603 & 5182 & 1325 & 2504 & 1551 & 3640 \\
$\quad$ manufacturing sector & 2118 & 5134 & 5137 & 564 & 770 & 857 \\
$\begin{array}{c}\text { Average population size } \\
\text { (in thousand) }\end{array}$ & 18,075 & 25,147 & 12,761 & 15,233 & 15,475 & 29,836 \\
$\begin{array}{c}\text { Average agricultural sector } \\
\text { growth rate }\end{array}$ & $6.0 \%$ & $8.5 \%$ & $5.0 \%$ & $5.5 \%$ & $5.0 \%$ & $7.9 \%$ \\
$\begin{array}{c}\text { Average manufacturing } \\
\text { sector growth rate }\end{array}$ & $3.4 \%$ & $10.3 \%$ & $8.2 \%$ & $-3.1 \%$ & $3.4 \%$ & $6.1 \%$ \\
$\begin{array}{c}\text { Average population growth } \\
\text { rate }\end{array}$ & $7.0 \%$ & $5.6 \%$ & $6.6 \%$ & $7.3 \%$ & $7.8 \%$ & $7.3 \%$ \\
$\begin{array}{c}\text { Difference between the } \\
\text { manufacturing sector } \\
\text { growth rate and the } \\
\text { population growth rate }\end{array}$ & $-3.7 \%$ & $4.7 \%$ & $1.6 \%$ & $-10.4 \%$ & $-4.4 \%$ & $-1.2 \%$ \\
\hline
\end{tabular}

Sources: Calculations made by the author based on data derived from the United Nations Conference on Trade and Development (UNCTAD) and Penn World Table (PWT) 7.0; Alan Heston, Robert Summers and Bettina Aten, Penn World Vision 7.0, Center for International Comparisons of Production, Income and Prices at the University of Pennsylvania, May 2011 
population. Their trends are such that the gap between the growth rate of manufacturing sector value added can be equated with that of the productivity of the sector, while the population growth rate of the entire continent is negative $(-3.7 \%)$. The population and the agricultural sector value added are increasing twice as fast as the manufacturing sector value added. The gap between manufacturing sector and population growth rates is also negative in West Africa (-10.4\%), Central Africa (-4.4\%) and East Africa (-1.2\%) but positive with respect to the population growth rates in North Africa (4.7\%) and Southern Africa (1.6\%). The differences in the manufacturing and agricultural sector growth rates are positive in North Africa and Southern Africa, and negative in Central, East and West Africa. The average growth rate of manufacturing sector value added for all the regions is positive. West Africa is the only region where it is negative $(-3.1 \%)$. North, East and West Africa have the largest agricultural sectors. Central Africa and Southern Africa have the smallest sectors. Consequently, we cannot consider that the population growth rate and the size of the agricultural sector are the main factors responsible for Africa's average manufacturing performance.

We used the medians and averages of manufacturing value added by region to determine differences. Their closeness implies that differences in the manufacturing sector performance of the countries of the zone are small, or even almost nil. However, where there is a gap, it could be due to differences in the creation of manufacturing value added in the countries of the region.

In most regions, the median values of agricultural value added are fairly close to the average values of the variable. The same is true for the value added of the manufacturing sector, with the exception of Southern Africa where there are wide differences.

To carry out a more in-depth statistical analysis at the regional level, we opted to differentiate between countries based on their performance. There are three types of countries. Countries with the highest median manufacturing sector performance are considered as leading countries. Those with the highest median agricultural sector performance are referred to as countries with great potential because they can develop a viable agri-food industry though with a fairly low level of manufacturing sector value added (below the regional median). A country is considered to have performed well when its median value added is higher than the regional median of the group to which it belongs. Countries that cannot be classified under one of these two groups are those that need agricultural sector capacity building. 
Based on this statistical analysis framework (Table 10.1), South Africa, Namibia and Botswana are regional industrial leaders in Southern Africa. Zambia is the only country in the region that has a great potential but does not seem to take advantage of it. In this group, Malawi, Mozambique and Zimbabwe need to be strengthened.

In North Africa, Morocco, Libya and Tunisia are leading countries, while Algeria and Egypt need to be strengthened.

For the other three regions, countries whose agricultural and/or manufacturing value added is close to that of those countries identified in the first two groups will be considered as leading countries or countries with great potential. We are obliged to use this approach because in these regions (West, Central and East Africa), the level of manufacturing value added per capita is much lower. The manufacturing median per capita in these three regions is about $80 \%$ less than that of North Africa and Southern Africa.

In East Africa where the agricultural median per capita is higher than that of Southern Africa, Kenya, Somalia and Sudan can be said to have an agro-industrial potential. Tanzania's agricultural sector needs to be strengthened. In Central Africa, Angola, Gabon and Equatorial Guinea have enormous potential. The agricultural and manufacturing sectors in Cameroon, which is the most industrially advanced country in the region, still need to be strengthened. The Central African Republic's agricultural sector in particular needs to be strengthened. In West Africa, Côte d'Ivoire is the only country with a level of manufacturing per capita close to that of the regional leaders identified. Although it is the regional leader, it has great potential like Ghana, Guinea-Bissau and Liberia. Benin, Senegal, Sierra Leone and Togo need agricultural capacity building. Overall, though North Africa and Southern Africa are leaders in the manufacturing sector, North Africa has the highest agricultural production level and the most stable group movement (in each of the sectors studied, the median is very close to the average). From the industrial viewpoint, the levels in Southern Africa are more diverse. For example, South Africa has a value of USD 808 per capita, while Botswana has a level of USD 175 per capita.

Structurally, the analysis in Table 10.4 shows that all the economic regions studied have a predominantly agricultural economic structure. 


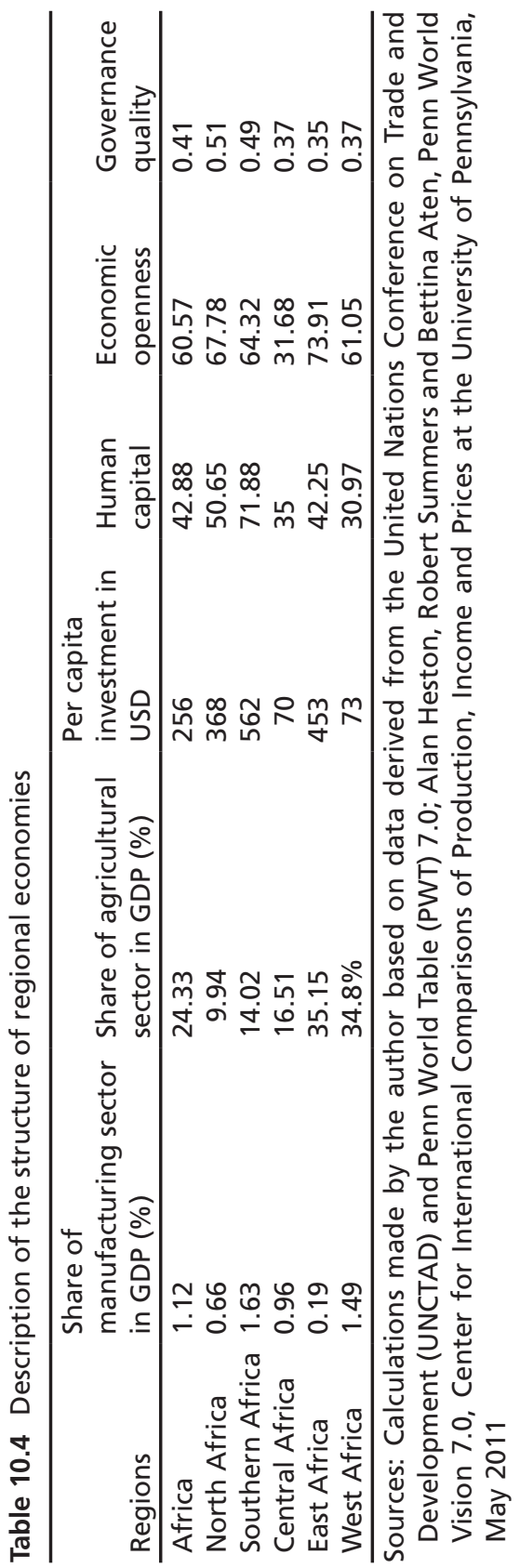


The share of manufacturing sector value added in gross domestic product (GDP) in North Africa is less than that in the West, Central and Southern Africa. East Africa has the lowest level on the continent. The only regions whose share of manufacturing sector value added in GDP is above the continental average (1.12\%) are Southern Africa (1.63\%) and West Africa (1.49\%). The share of manufacturing sector value added in GDP of the other three regions, namely North, Central and East Africa, is below this average. Besides boosting productivity in various sectors, the objective of promoting structural change has not been achieved. Our approach is therefore well adapted to all the regions included in our study sample.

The analysis in Table 10.5 also shows that there is a positive correlation between the manufacturing value added and control variables, namely levels of investment per capita, human capital, degree of economic openness and governance quality. There is also a positive correlation between all variables and the agricultural sector value added.

\subsection{Findings}

It should be recalled that agricultural sector value added is the important variable in this study and that investment, human capital, economic openness and governance quality have been considered in our regressions. The different results obtained using fixed effects models, twin effects models (with temporal dummies) and the generalized least-squares estimator are very similar. The results of regressions using fixed effects models and random effects models for Southern Africa and North Africa (Table 10.6), Central Africa, East Africa and West Africa (Table 10.7) and the dynamic regression panel model using the generalized leastsquares estimator (Table 10.8) are summarized in Table 10.9.

This section first presents a number of implications related to the links that exist between the two sectors under study and then those related to the control variables used.

The analysis shows that some regions of Africa have a great potential for achieving industrial development through primary products processing or 


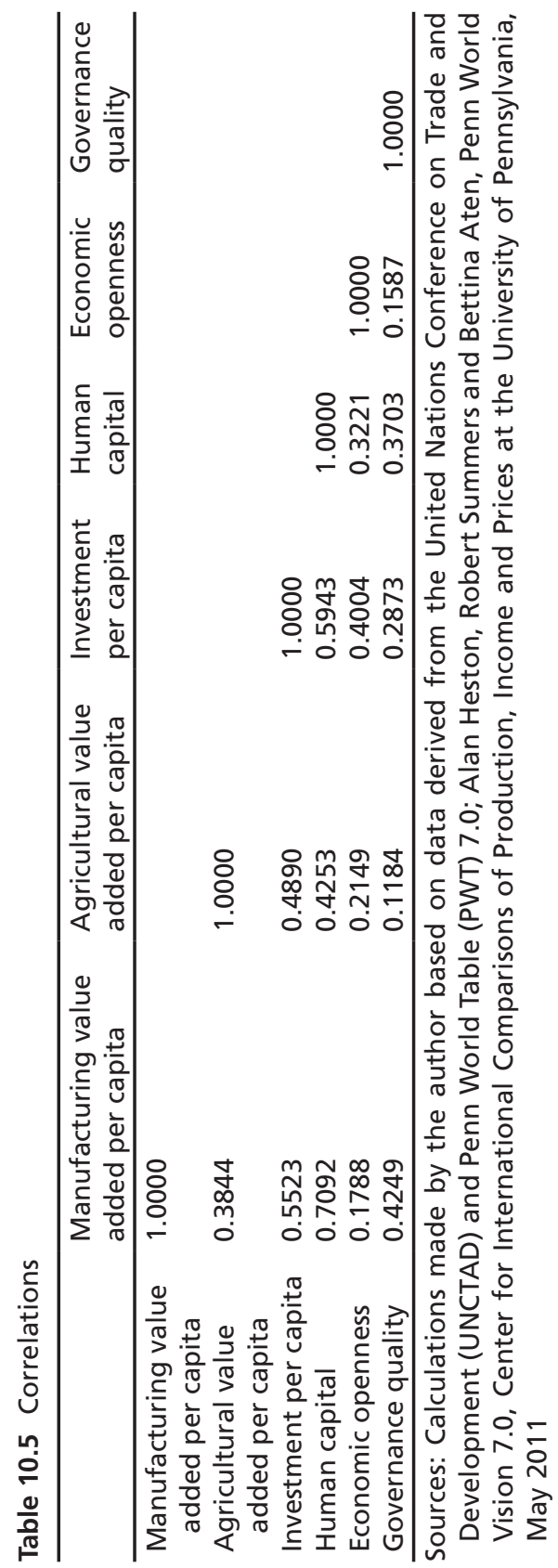




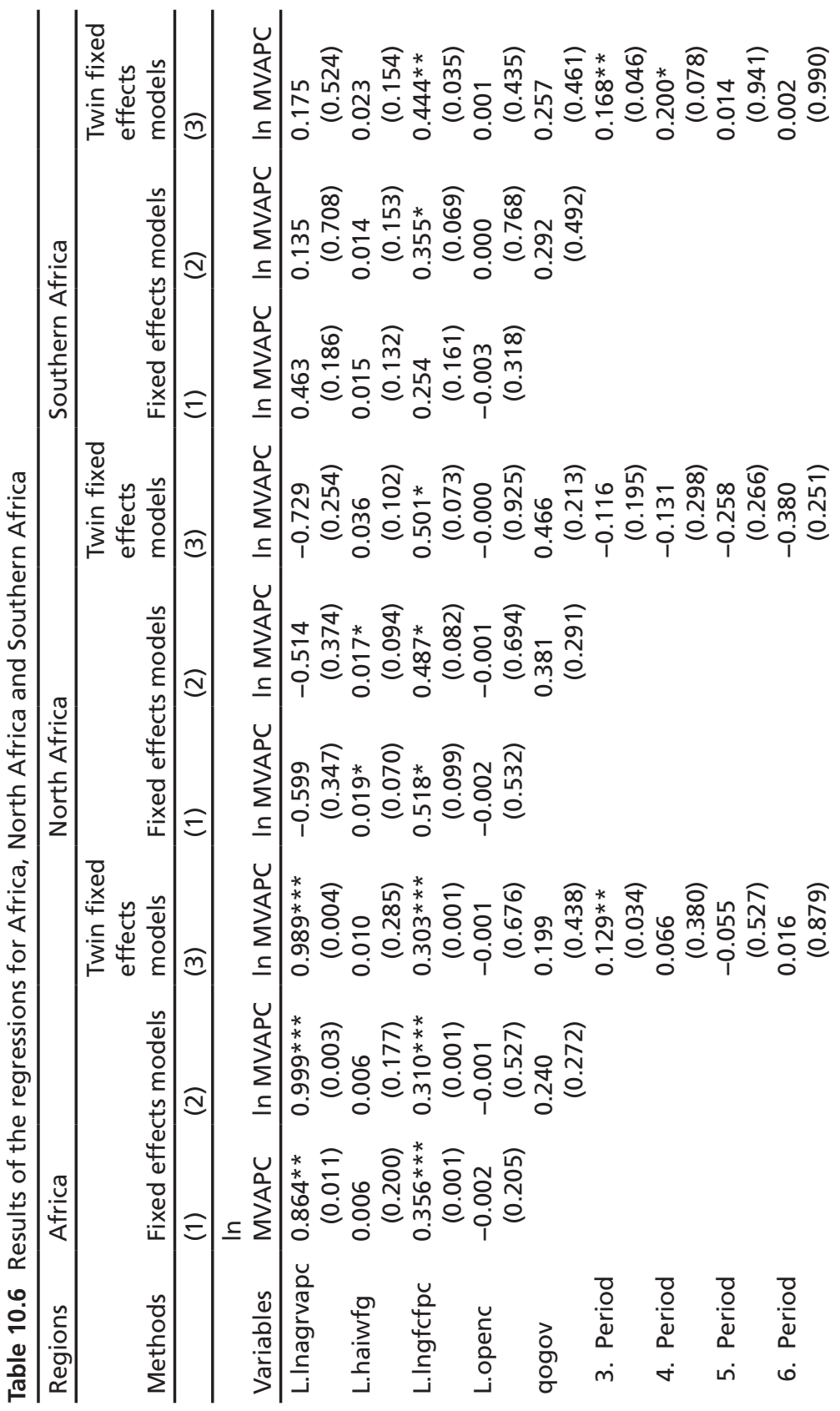




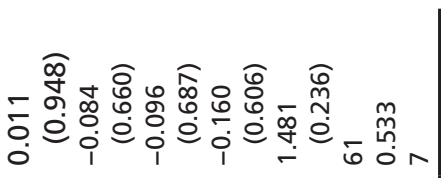

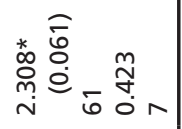

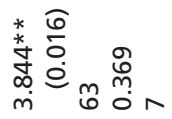

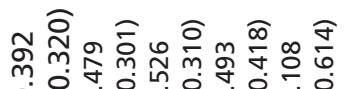

î

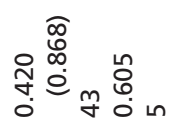

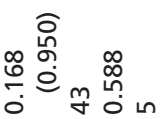

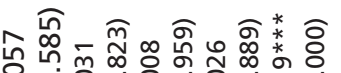

กิ้น

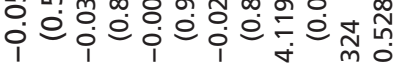

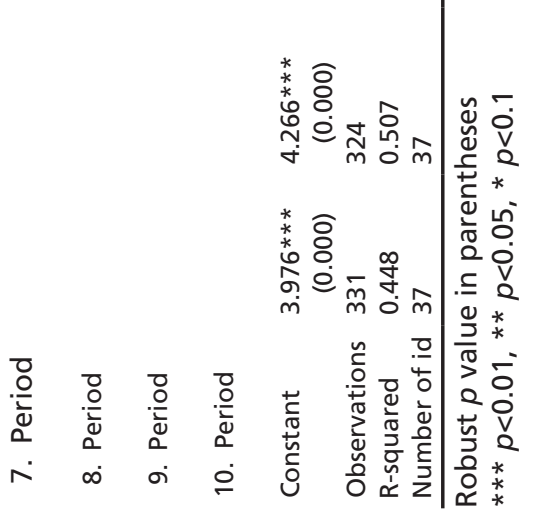




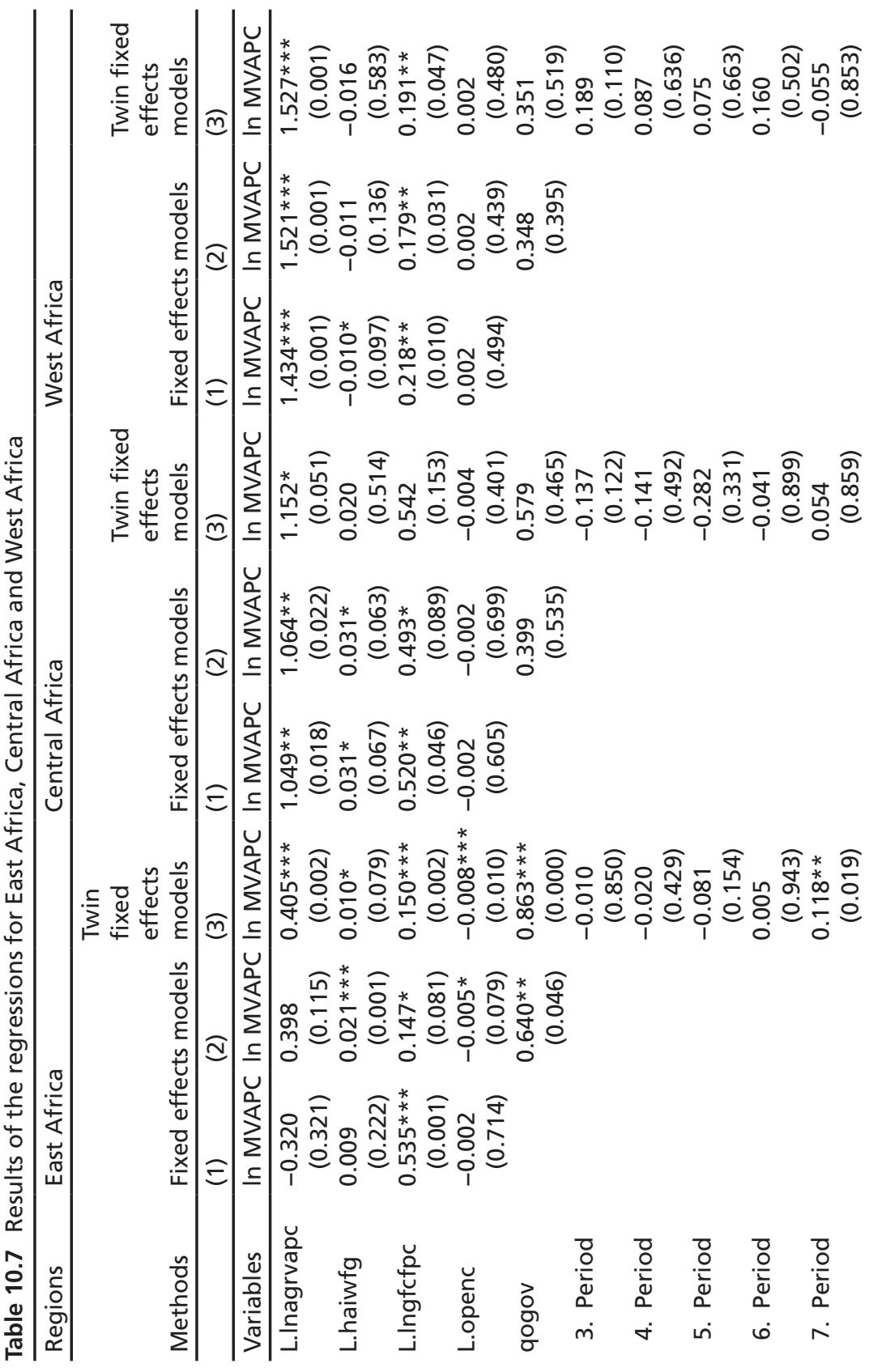




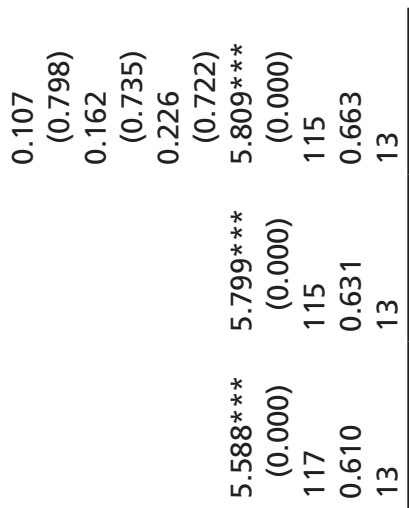

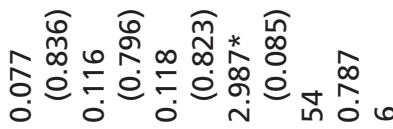

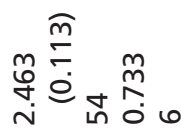

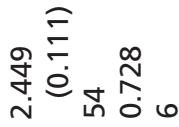

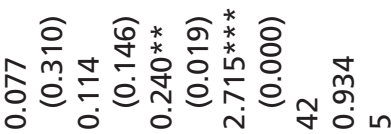

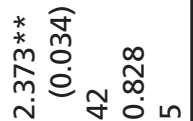

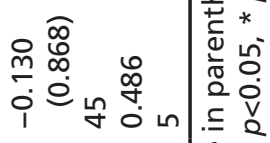

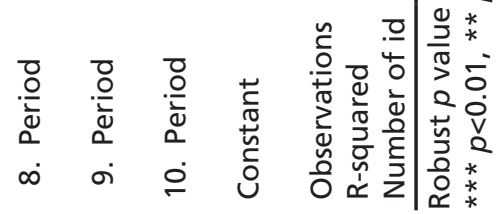


Table 10.8 Dynamic regression panel model

\begin{tabular}{ll}
\hline Region & Africa \\
\hline Methods & $\begin{array}{l}\text { Two-step generalized least-squares } \\
\text { estimator }\end{array}$ \\
\hline & $(1)$ \\
\hline Variables & In MVAPC \\
\hline L.InMVAPC & $0.516^{* * *}(0.000)$ \\
Inagrvapc & $0.696^{* * *}(0.000)$ \\
haiwfg & $-0.005(0.645)$ \\
Ingfcfpc & $0.087^{* *}(0.049)$ \\
openc & $0.003(0.106)$ \\
qogov & $0.141(0.523)$ \\
2bn. Period & $0.424(0.150)$ \\
3. Period & $0.331(0.223)$ \\
4. Period & $0.379(0.152)$ \\
5. Period & $0.211(0.486)$ \\
6. Period & $0.146(0.561)$ \\
7. Period & $0.771^{* * *}(0.002)$ \\
8. Period & $0.297^{*}(0.073)$ \\
9. Period & $0.308^{*}(0.059)$ \\
Observations & 288 \\
Number of id & 37 \\
Arellano-Bond test for AR(1) & $-2.88^{*}(0.04)$ \\
Arellano-Bond test for AR(2) & $-1.48(0.14)$ \\
Sargan test of overidentification & $15.59(0.96)$ \\
restrictions & \\
Hansen test of overidentification & $14.86(0.971)$ \\
Number of instruments & 41 \\
\hline P value in parentheses &
\end{tabular}

$p$ value in parentheses

$* * * p<0.01, * * p<0.05, * p<0.1$

Table 10.9 Results and estimates

\begin{tabular}{|c|c|c|c|c|c|c|}
\hline Variables & $\begin{array}{l}\text { Africa } \\
\text { (Bulk } \\
\text { Sample) }\end{array}$ & $\begin{array}{l}\text { North } \\
\text { Africa }\end{array}$ & $\begin{array}{l}\text { Southern } \\
\text { Africa }\end{array}$ & $\begin{array}{l}\text { Central } \\
\text { Africa }\end{array}$ & $\begin{array}{l}\text { West } \\
\text { Africa }\end{array}$ & East Africa \\
\hline $\begin{array}{l}\text { Agricultural } \\
\text { sector value } \\
\text { added }\end{array}$ & $0.516 * * *$ & (Ø) & (Ø) & $1.152^{*}$ & $1.527 * * *$ & $0.405^{* * *}$ \\
\hline Investment & $0.087^{* *}$ & $0.501 *$ & $0.444 * *$ & $0.493^{*}$ & $0.191 * *$ & $0.150 * * *$ \\
\hline Human capital & (Ø) & (Ø) & (Ø) & $(\varnothing)$ & $(\varnothing)$ & $0.010 *$ \\
\hline $\begin{array}{l}\text { Economic } \\
\text { openness }\end{array}$ & (Ø) & (Ø) & (Ø) & (Ø) & (Ø) & $-0.008 * * *$ \\
\hline $\begin{array}{l}\text { Governance } \\
\text { quality }\end{array}$ & (Ø) & (Ø) & (Ø) & (Ø) & (Ø) & $0.863 * * *$ \\
\hline
\end{tabular}


use of another form of agricultural surplus. We have demonstrated that there is a positive statistical correlation between agricultural and manufacturing sector value added. We have also underscored the positive impact of the agricultural sector on the manufacturing sector in Africa as well as in some regions. If the African continent seeks to achieve industrial development by following the path we have proposed, it should establish an entity responsible for implementing an appropriate industrialization policy and designing industrial policy implementation support and monitoring tools. Thus, it could be in a position to support national and regional economies in formulating their industrial policies and developing tools to implement and monitor such policies, taking into account the conditions and structure of each economy.

Despite some similarities, potential and, hence, results differ according to region. It was observed that some regions such as North Africa and Southern Africa have the best manufacturing, agricultural, investment, human capital, economic openness and governance quality performance. It was also realized that such performance could not bring about change in the structure of the economies of these regions which are still dominated by the agricultural sector. In addition, the size of the agricultural sector does not seem to produce any impact on the manufacturing sector in these two regions which apparently produce mainly agricultural products for local consumption or export. Thus, to build agro-based industries, countries in these regions should first of all reorient the use of agricultural products, while making the necessary investments. These are merely options for improving manufacturing value added, given that the two regions have clearly opted for an industrialization model that differs from our structural change approach. They can, however, adopt the approach. As indicated earlier, these regions have the highest levels of manufacturing value added, but the manufacturing sector's share in the economy suggests that structural change is in progress.

The level of manufacturing in Central, West and East Africa, unlike in Southern Africa and North Africa, is low. West and Central Africa have the highest agricultural sector contribution to the manufacturing sector with a low total agricultural value added and the lowest manufacturing value added on the continent. The agricultural sector's contribution to the 
manufacturing sector in East Africa is positive, but low. The very small share of manufacturing value added in total value added suggests that these regions should make more investments in agricultural production and adopt measures to ease the transfer of agricultural surplus to the manufacturing sector. This weakness may highlight the lack of an industrial policy or inadequate application thereof to develop the agri-food industry.

The analysis of these results shows that it is necessary to improve human capital in Africa in order to promote change in the continent's economic structure and in the various regions. This reflects the need to provide appropriate training and disseminate knowledge to foster knowledge absorption, improve productivity and promote structural change.

The absence or negative impacts of economic openness underscore the need to improve countries' trade policies and build trade capacity to achieve greater global trade integration. Trade with the outside world does not promote the development of the agri-food industry. Thus, it does not adequately promote technology and scientific knowledge dissemination. There is need to adopt a trade-opening policy that promotes structural change.

The absence of governance quality impacts makes it necessary to strengthen countries' institutional structures and tailor them to their needs. At any rate, it is necessary to improve governance quality to ensure the proper selection of investments and successful implementation of adapted economic policies.

In Central Africa, investment is making a significant contribution and should be sustained and promoted to enhance the development of the manufacturing sector. The agricultural products value added should also be improved to promote structural change.

The manufacturing sector's share in West African countries' GDP is one of the highest on the continent, but certainly one of the lowest among developing countries worldwide. The improvement of investments in both sectors will not only promote their development, but also improve the overall impact of investment, which is very low.

In East Africa, efforts should mainly focus on governance quality, which is the most important element of industrial development in the region. 
As we have seen, West and Central Africa have much better results. East Africa can achieve similar results, but negative shocks, though temporary, may limit the impact of such results.

Although Southern Africa and North Africa have the highest level of manufacturing sector performance, they are no longer leaders in agricultural products processing or the mobilization of agricultural surplus. West and Central Africa have the highest contribution.

\subsection{Conclusion}

This study focused on an industrial development model based on agricultural production. First, we reviewed the works of Lewis (1954), Mellor J. W. (1966) and Kuznets (1973) to circumscribe the topic. This helped to better understand the link between the agricultural and manufacturing sectors as well as the mechanisms through which the agricultural sector promotes the development of manufacturing activities.

In the approach adopted, we followed in the footsteps of these preceding authors by underscoring the size of the agricultural sector as a prerequisite for industrial take-off. Next, global and regional statistical analyses showed that countries with the highest level of manufacturing activities in Africa also enjoy good agricultural performance. This group includes South Africa, Swaziland, Namibia, Morocco, Libya, Tunisia, Central African Republic, Cameroon, Gabon, Botswana, Côte d'Ivoire and Ghana as potential leaders of industrialization in Africa.

We obtained relevant results concerning industrialization based on agricultural products. The econometric regressions conducted suggest that it is not easy for all countries to adopt this development model. North Africa and Southern Africa have the highest levels of manufacturing value added. When the different factors that influence manufacturing value added in Africa are considered, it becomes quite clear that the size of the agricultural sector is not necessarily the element that promotes the industrial development of these regions. In addition, our results enabled us to identify the regions that seem to benefit most from the impacts of agricultural 
sector development on the manufacturing sector, namely West and Central Africa. Yet, these regions are among those with the lowest manufacturing value added in Africa. Despite this low value creation, we were able to reclassify the regions according to contribution, based on the value and significance of the coefficient associated with agricultural value added. According to this new classification, West Africa is followed by Central Africa and then by East Africa, whose performance is undermined by the negative effects of temporary shocks.

Southern Africa and North Africa are at the bottom of the ranking for the simple reason that they mainly produce for export or local consumption. This is reflected in their high levels of manufacturing and agricultural sector value added, but without any significant contribution to the first sector.

We were able to identify some of the factors responsible for the weakness of the agricultural sector-based industrial development model in Africa. These include low skill-development potential or level of human capital, the educational thrusts chosen, the educational and skills utilization policies, poor infrastructure, low level of investment and poor targeting of investments, the adoption of trade policies that do not promote this type of industrial development and the acute need for institutional capacity building that could certainly promote such structural change. These elements have enabled us to make some recommendations to improve manufacturing sector value added. These include the implementation of agricultural and industrial sector development support policies, the redefinition of educational policies, the development of transport infrastructure, more effective targeting of investments to be made, the adoption of a trade policy that promotes economic integration, the use of technology and efforts to improve governance quality. 


\section{Annexes: Agricultural and Manufacturing Sector Value Added by Region}

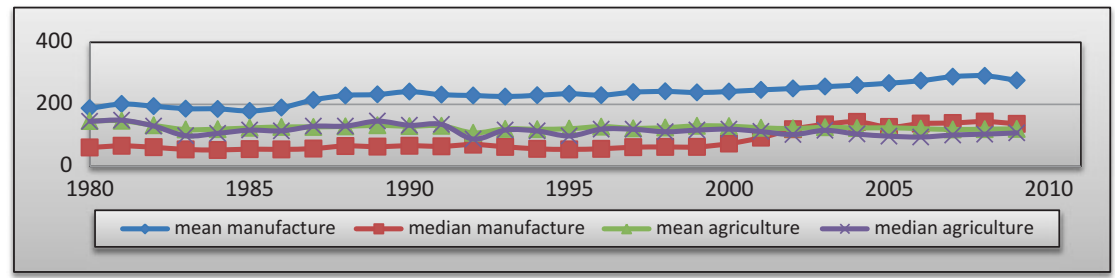

Graph 10.4 Southern Africa. Sources: Calculations made by the author based on data derived from the United Nations Conference on Trade and Development (UNCTAD) and Penn World Table (PWT) 7.0; Alan Heston, Robert Summers and Bettina Aten, Penn World Vision 7.0, Center for International Comparisons of Production, Income and Prices at the University of Pennsylvania, May 2011

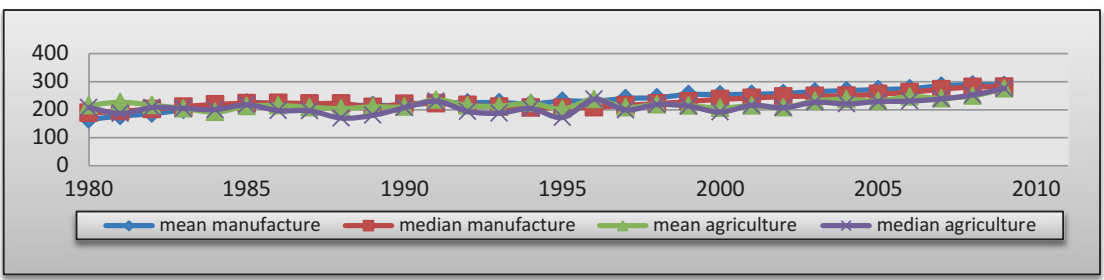

Graph 10.5 North Africa. Sources: Calculations made by the author based on data derived from the United Nations Conference on Trade and Development (UNCTAD) and Penn World Table (PWT) 7.0; Alan Heston, Robert Summers and Bettina Aten, Penn World Vision 7.0, Center for International Comparisons of Production, Income and Prices at the University of Pennsylvania, May 2011 


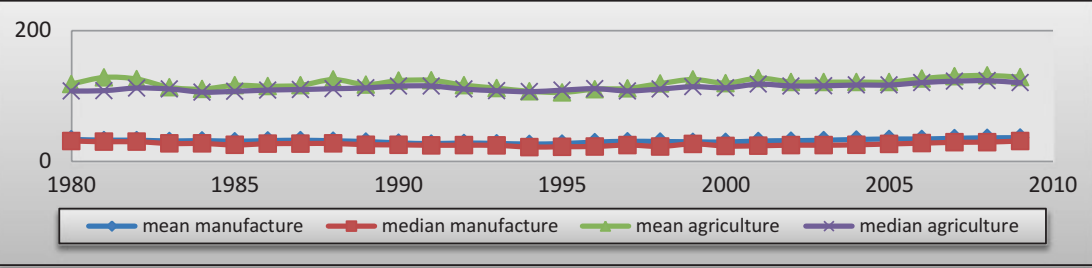

Graph 10.6 East Africa. Sources: Calculations made by the author based on data derived from the United Nations Conference on Trade and Development (UNCTAD) and Penn World Table (PWT) 7.0; Alan Heston, Robert Summers and Bettina Aten, Penn World Vision 7.0, Center for International Comparisons of Production, Income and Prices at the University of Pennsylvania, May 2011

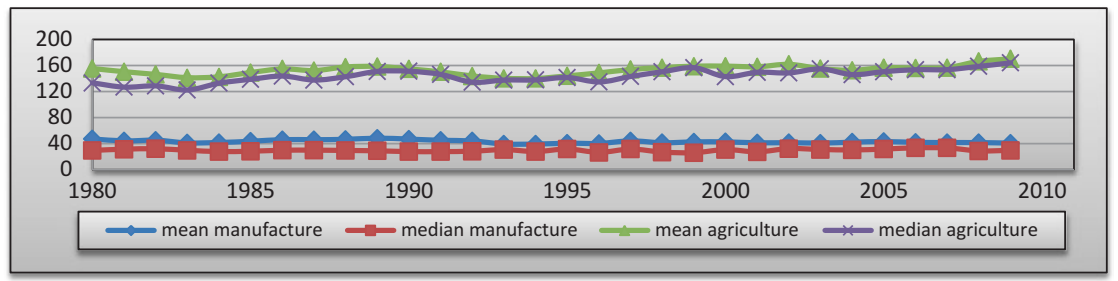

Graph 10.7 West Africa. Sources: Calculations made by the author based on data derived from the United Nations Conference on Trade and Development (UNCTAD) and Penn World Table (PWT) 7.0; Alan Heston, Robert Summers and Bettina Aten, Penn World Vision 7.0, Center for International Comparisons of Production, Income and Prices at the University of Pennsylvania, May 2011

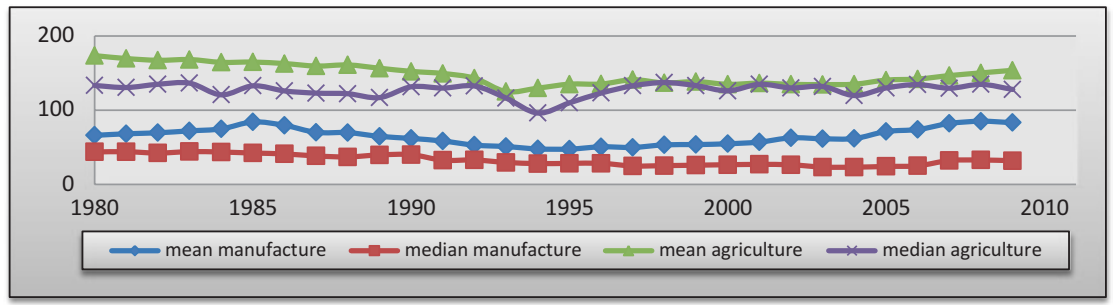

Graph 10.8 Central Africa. Sources: Calculations made by the author based on data derived from the United Nations Conference on Trade and Development (UNCTAD) and Penn World Table (PWT) 7.0; Alan Heston, Robert Summers and Bettina Aten, Penn World Vision 7.0, Center for International Comparisons of Production, Income and Prices at the University of Pennsylvania, May 2011 


\section{Note}

1. Benin, Burundi, Cape Verde, Central African Republic, Chad, Comoros, Djibouti, Eritrea, Equatorial Guinea, Lesotho, Mauritania, Mauritius, Rwanda, Sao Tome and Principe, Seychelles and Swaziland.

\section{References}

Abdelmalki, L., \& Mundler, P. (1995). Economie du développement, les théories, les expériences et les perspectives (311 pages). Paris: Hachette Supérieur.

Arellano, M., \& Bond, S. (1991). Some Tests of Specification for Panel Data: Monte Carlo Evidence and an Application to Employment Equations. Review of Economic Studies, Wiley Blackwell, 58(2), 277-297.

Arellano, M., \& Bover, O. (1995). Another Look at the Instrumental Variable Estimation of Error-Components Models. Journal of Econometrics, Elsevier, 68(1), 29-51.

Auty, R. M. (2000). How Natural Resources Affect Economic Development. Development Policy, 18, 347-364.

Bairoch, P. (1971). Le Tiers-Monde dans l'impasse: le démarrage économique du XVIIIe au XXe siècle (Vol. 250). Paris: Gallimard.

Balassa, B. (1979). The Changing Pattern of Comparative Advantage in Manufactured Goods. The Review of Economics and Statistics, 61(2), 259-226. Barro, J. (1998). Determinants of Economic Growth: A Cross-Country Empirical Study (Vol. 1, 1st ed.). Cambridge, MA: The MIT Press.

Blundell, R., \& Bond, S. (1998). Initial Conditions and Moment Restrictions in Dynamic Panel Data Models. Journal of Econometrics, 87(1), 115-143.

Collier, P. (2002). Primary Commodities Dependence and Africa's Future (26 pages). Washington, DC: World Bank.

Cornwall, J. (1977). Modern Capitalism: Its Growth and Transformation. London: Martin Robertson.

ECA, \& AUC. (2013). Economic Report on Africa 2013: "Making the Most of Africa's Commodities: Industrializing for Growth, Jobs and Economic Transformation". Addis Ababa: United Nations Publication, E.13.II.K.1.

Fei, J. C., \& Ranis, G. (1969). Economic Development in Historical Perspective. The American Economic Review, 59, 386-400.

Fondation pour les Etudes et la Recherche sur le Développement International (FERDI). (2011). Human Asset Index Computing Retrospective Series from 1970-2008. 55 pages. 
Hawkins, A. M. (1986). Can Africa Industrialize? In Strategies for African Development (pp. 279-307). Berkeley, CA: University of California Press. Hughes, H. (1984). Industrialization and Development: A Stocktaking. Industrialisation and Development. A Third World Perspective. Westport: Greenwood Press.

Kuznets, S. (1966). Modern Economics and Growth: Rate Structure and Spread. New Haven and London: Yale University Press.

Kuznets, S. (1973). Modern Economic Growth: Findings and Reflections. The American Economic Review, 63, 247-258.

Lewis, W. A. (1954). Economic Development with Unlimited Supplies of Labour. The Manchester School, 22, 139-191.

Mayer J., \& Fajarnes P. (2008). Tripling Africa Primary Exports: What? How? Where? UNCTAD Discussion Papers 191, United Nations Conference on Trade and Development, 39 pages.

Mellor, J. W. (1966). The Economics of Agricultural Development. Ithaca: Colonel University Press.

Park, B., \& Lee, K.-K. (2006). Natural Resources, Governance, and Economic Growth in Africa. Journal of International Economic Studies, 10(2), 1598-2769.

Roodman, D. (2006). How to Do xtabond2: An Introduction to "Difference" and "System" GMM in Stata. Stata Journal, StataCorp LP, 9(1), 86-136, 53 pages.

Shifa, A. B. (2011). Does Agricultural Growth Have a Causal Effect on Manufacturing Growth? (13 pages). Stockholm: Institute for International Economic Studies, Stockholm University.

Studennund, A. H. (2000). Using Econometrics: A Practical Guide (4th ed.). Boston, MA: Addison-Wesley.

Szirmai A., \& Verspagen B. (2011). Manufacturing and Economic Growth in Developing Countries, 1950-2005, wp2011-069, Maastricht Economic and Social Research and training Centre on Innovation and Technology, United Nations University (UNU-MERIT) and Maastricht University, The Netherlands, 41 pages.

Tregenna, F. (2007). Which Sectors Can Be Engines of Growth and Employment in South Africa? An Analysis of Manufacturing and Services. UNU-WIDER Conference on 'Southern Engines of Global Growth: China, India, Brazil and South Africa', Helsinki, Finland, Vol. 7.

United Nations Conference for Trade and Development. (2013). Intra-African Trade: Unlocking Private Sector Dynamism, 158 pages. 
United Nations Conference for Trade and Development Database. (2011). http://unctadstat.unctad.org/ReportFolders/reportFolders.aspx?sCS_ referer=\&sCS_ChosenLang=fr.

Wiggins V. (2003). http://www.stata.com/statalist/archive/2003-10/msg00031. html.

Wood, A., \& Mayer, J. (2001). Africa's Export Structure in a Comparative Perspective. Cambridge Journal of Economics, 25(3), 369-394.

Open Access This chapter is licensed under the terms of the Creative Commons Attribution 4.0 International License (http://creativecommons.org/licenses/ by/4.0/), which permits use, sharing, adaptation, distribution and reproduction in any medium or format, as long as you give appropriate credit to the original author(s) and the source, provide a link to the Creative Commons license and indicate if changes were made.

The images or other third party material in this chapter are included in the chapter's Creative Commons license, unless indicated otherwise in a credit line to the material. If material is not included in the chapter's Creative Commons license and your intended use is not permitted by statutory regulation or exceeds the permitted use, you will need to obtain permission directly from the copyright holder.

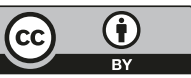

